\title{
Community patterns of coral-associated decapods
}

\author{
Nicholas J. Gotelli and Lawrence G. Abele \\ Department of Biological Science, Florida State University, Tallahassee, Florida 32306, USA
}

\begin{abstract}
Community patterns of abundance and co-occurrence are described for decapod crustaceans associated with the coral Pocillopora damicornis in the Eastern Pacific Ocean. Most reef flank (deep) corals have lower densities of decapods than reef flat (shallow) corals. This difference affects the species-area relation for the 2 habitats. Seasonally, abundance is highest in June and April, lowest in August and January. However, the species-area relation does not differ greatly through time. Most coral heads support fewer species than expected if the individuals from a sample were distributed randomly among heads. Principal components analysis did not reveal any distinct patterns of covariation among species' densities. Likewise, pairwise comparisons between common species revealed few, if any, significant correlations of abundance or co-occurrence. These results suggest a considerable degree of independence in the density and occurrence of decapod species associated with Pocillopora.
\end{abstract}

\section{INTRODUCTION}

Decapod crustaceans are the most abundant macroinvertebrates inhabiting the branching coral Pocillopora (Patton, 1974; Abele and Patton, 1976; see also Reed et al., 1982 for a different coral community). Many of these decapod species are obligate symbionts of live pocilloporid corals and feed on coral mucus (Knudsen, 1967; Patton, 1974). The fauna is relatively well known. Modern collections have been taken in the Eastern Pacific Ocean (Abele, 1976a, b; Abele and Patton, 1976; Glynn, 1976; Abele, 1979; Castro, in press), Hawaii (Barry, 1965; Preston, 1971, 1973; Coles, 1980), Central Pacific Ocean (Garth, 1964; Knudsen, 1967), Indian Ocean (Garth, 1974), and Australian waters (Patton, 1966, 1974; Austin et al., 1980; Abele, in press).

Glynn $(1973,1976)$ has made detailed studies of the branching coral Pocillopora damicornis (Linnaeus) in the Eastern Pacific. In one study (Glynn, 1976), 119 heads of Pocillopora were collected from Uva Island, a patch reef in the Gulf of Chiriqui, Panama. Glynn (1976) reported on the distribution and abundance of the most conspicuous symbionts, the xanthid crab Trapezia spp. and the snapping shrimp Alpheus lottini Guerin. These species actively defend their coral host from attacks by the predatory crown-of-thorns seastar Acanthaster planci (Linnaeus) (cf. Glynn, 1976, 1980).

Here, we examine Glynn's (1976) Uva Island collections with respect to 2 major community patterns: species-area relationships (Abele, 1976a, 1979) and interspecific association. In this analysis, we compare species-area relationships for different locations (flat vs. flank following the terminology of Glynn, 1976) and seasons on the same reef. The effect of species' abundances on the species-area relationship is also assessed. This important factor is usually ignored in species-area comparisons (Haila and Järvinen, 1981).

In addition to the area effect, interspecific interactions may influence patterns of abundance and cooccurrence. If competition were to influence community structure, pairs of interacting species might be negatively correlated or associated with each other. Likely competitors in the Pocillopora community are xanthid crabs of the genus Trapezia. Trapezia spp. are obligate associates of live pocilloporid corals (Castro, 1976). Adult crabs often associate as male-female pairs (Preston, 1971, 1973), and individuals frequently migrate between coral heads (Castro, 1978). Both intraand interspecific agonistic interactions have been reported between adult pairs (Preston, 1971, 1973), and in Hawaii, some species of Trapezia are negatively associated in occurrence (Preston, 1973). Here, we report indices of association and correlation (Hurlbert, 1969), which may reflect interactions between pairs of species (or indirect interactions that occur through the influence of a third species; Whittam and SiegelCausey, 1981).

Community patterns may be detected on a broader scale if groups of interacting species covary in their abundance or occurrence. These patterns would not necessarily emerge from pairwise comparisons of a few 
species. A principal components analysis is one way of detecting patterns of covariation among groups of species (Pielou, 1977). A principal components solution defines new orthogonal variables, which account for variation in the densities of all species considered.

The descriptive approach has a strong tradition in community ecology (MacArthur, 1972). However, the dangers of overinterpreting non-experimental data are becoming more apparent in community studies (Hairston, 1981; Lawton and Strong, 1981). Because this analysis is only descriptive, mechanistic explanations cannot be firmly attached to any patterns that emerge. Instead, the results should be used to suggest hypotheses that warrant closer study.

\section{MATERIALS AND METHODS}

The study site at Uva Island is a patch reef $100 \mathrm{~m}$ off shore in the Gulf of Chiriqui (Glynn et al., 1972; Glynn, 1976). Sea surface temperatures are relatively constant year-round. Seasonal upwelling has not been detected at this site. Annual sea surface salinity ranges from 31 to $33 \mathrm{ppt}$, and sea surface temperature ranges from 28 to $29^{\circ} \mathrm{C}$ (Abele, 1976b). The Gulf of Chiriqui experiences distinct wet and dry seasons, with high rainfall, increased sedimentation, and reduced salinity and visibility during the wet season, from May to November (Dana, 1975). The maximum tidal range is $5 \mathrm{~m}$ at Uva Island, and reef flat corals occasionally suffer extensive mortality from low-tide exposures (Glynn, 1976).

Pocillopora cover ranges from 40 to $80 \%$ on the reef flat, with near continuous cover on the reef crest. Pocillopora cover on the reef flank drops off quickly with depth. Almost no pocilloporid corals are found below 6 m (cf. Glynn, 1976: Fig. 2)

Coral heads were collected by P. W. Glynn in 1973. Upon collection, corals were sealed in plastic bags and carried to the surface (Abele and Patton, 1976; Glynn, 1976). L. G. Abele, in 1973, sorted the samples, measured the corals and identified the associated decapod crustaceans. All epifaunal organisms were removed from the live portions of the coral; animals associated with the deal coral base were excluded. A single endolithic gall crab, Haplocarcinus marsupialis Stimpson, was collected, but not included in these analyses. Coral volume was estimated by $1 \times w \times h$, measured in centimeters. The collection of 119 coral heads yielded 52 species and 4724 individuals of decapods. Coral heads were collected from the reef flank and reef flat in January (flank $n=28$, flat $n=28$ ), April (flank $n=12$, flat $n=17$ ), June (flank $n=12$, flat $n=12$ ) and August (flank $\mathrm{n}=5$, flat $\mathrm{n}=5$ ).

Unfortunately, the January samples were pooled before it was realized that the Trapezia belonged to 3 species, not to 1 . Two of the species, $T$. ferruginea Latreille and $T$. corallina Gestaecker, are very common, while $T$. formosa Smith is very rare. Therefore, all of the January samples were increased by 1 species. The species-area analysis was repeated without the January data, and the results did not change. For the partial correlation coefficients and the principal components analysis, only complete samples were used $(\mathrm{n}=58)$. The influence function, which identifies influential cases in least-squares regressions, was computed from the procedure in Weisberg (1980). Regressions, partial correlation coefficients, and the principal components analysis were calculated by SPSS, version 9.0. All computations were performed on the Cyber 760 computer, at Florida State University.

\section{RESULTS}

\section{Patterns of species richness}

Species number is significantly correlated with both coral head size and abundance of individuals (Fig. 1a, b). Typically, these relationships are plotted on a log$\log$ scale. However, for these data, a square root $y$ vs. $\log _{10} x$ transformation provided a slightly better linear fit. These transformations were selected by examination of residual plots. The log-log model gave similar results, but the residuals did not appear as normally distributed, so the square root transformation was favored. In this case, we wished to test more detailed regression models, so a good linear fit was important. Actually, both transformations describe a biologically realistic curve that increases asymptotically as area is increased.

Although area is well correlated with species number over several orders of magnitude, there is considerable scatter in the data; coral head size explains only $30 \%$ of the variation in species number. Some of the scatter may result because data from 4 different times and 2 different locations are plotted together. In an attempt to explain more residual variance, analysis of covariance models were tested that include parameters for season, location, and density (Table 1).

There are no statistical differences in either the slope or the intercept of the species-area relationship at different times. However, a significant pattern was detected for differences in location. The slope of the reef flank samples is significantly steeper than that of the reef flat samples $\left(F_{1,115}=5.07, p<.05\right)$. The intercepts do not differ significantly $\left(F_{1,116}=1.89, p>05\right)$. Inclusion of the slope term adds about $10 \%$ more variance explained in species number.

For the species-area relation, most observations had 
Fig. 1. (A) Species-area plot for Pocillopora decapods; regression equation: square root (species number $)=0.121+0.907 \quad\left(\log _{10}\right.$ coral head size); $\mathrm{R}^{2}$ adjusted $=0.30$. (B) Species-individuals plot for Pocillopora decapods; regression equation: square root (species number) $=1.08+1.33$ $\left(\log _{10}\right.$ abundance); $\mathrm{R}^{2}$ adjusted $=0.61$ (C) Individuals-area plot for Pocillopora decapods; regression equation: square root (abundance $)=-8.01+4.28\left(\log _{10} \mathrm{cor}-\right.$ al head size); $R^{2}$ adjusted $=0.44$. (D) Species-area regressions for reef flank and reef flat samples. Reef flank: $\mathrm{Y}=-1.14+1.27 \mathrm{x}$; $\mathrm{R}^{2}$ adjusted $=0.38$. Reef flat: $\mathrm{Y}=0.868+0.691 \mathrm{x} ; \mathrm{R}^{2}$ adjusted $=0.25$. Open circles $=$ reef flat samples; closed circles $=$ reef flank samples. (E) Individualsarea regressions for reef flat and reef flank samples. Reef flank: $\mathrm{Y}=-13.80+5.87 \mathrm{x} ; \mathrm{R}^{2}$ adjusted $=0.56$. Reef flat: $Y=-5.29+$ $3.52 \mathrm{x} ; \mathrm{R}^{2}$ adjusted $=0.41$. Open circles $=$ reef flat samples; closed circles $=$ reef flank samples. $(\mathrm{F})$ Factor loadings for a principal components analysis of species densities; factor loadings on the first (PCI) and second (PCII) axes are shown. Circles $=$ palaemonids; squares = majids; triangles $=$ alpheids; open hexagons $=$ xanthids; closed hexagons $=$ porcellanids. $1=$ Trapezia ferruginea; $2=$ Trapezia corallina $3==$ Trapezia formosa
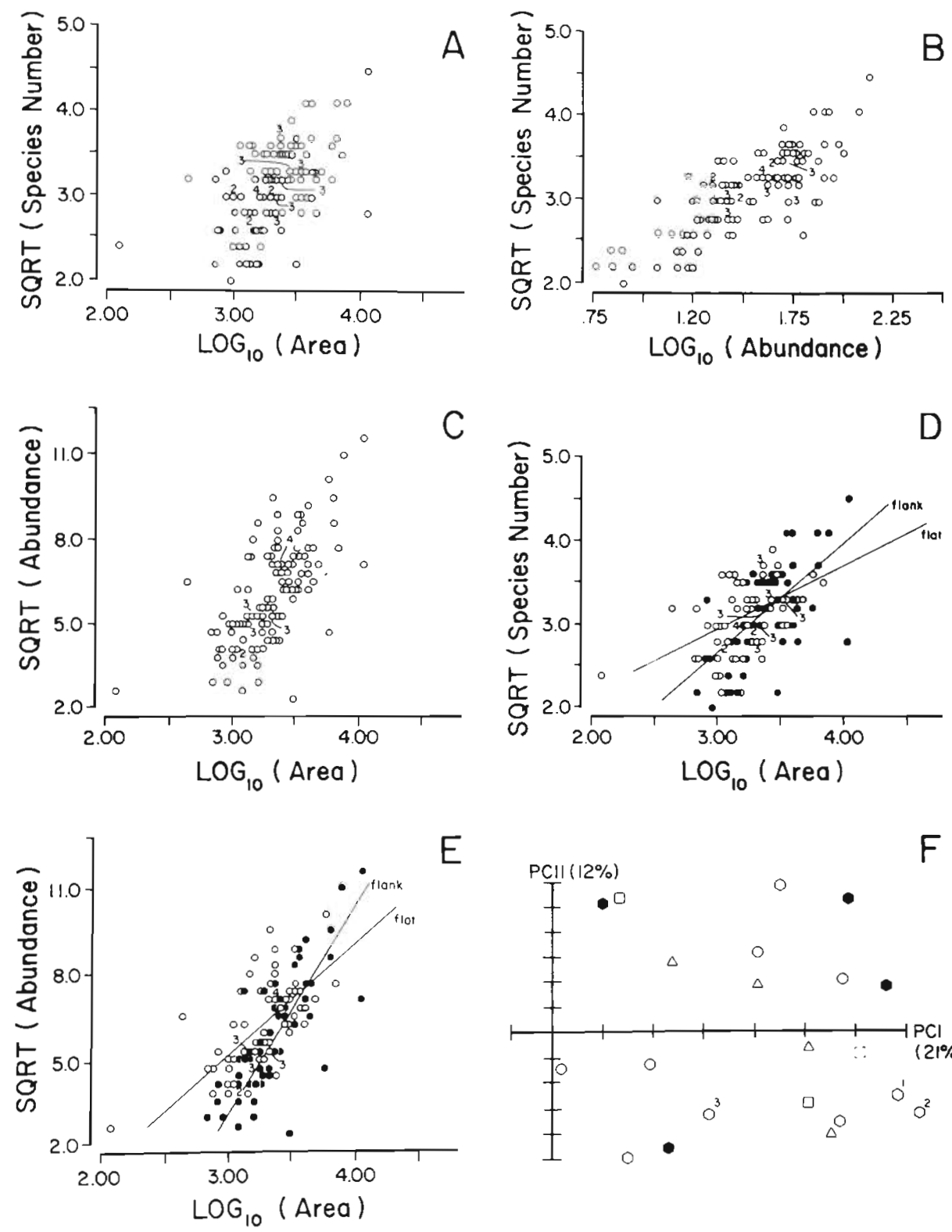

$E$

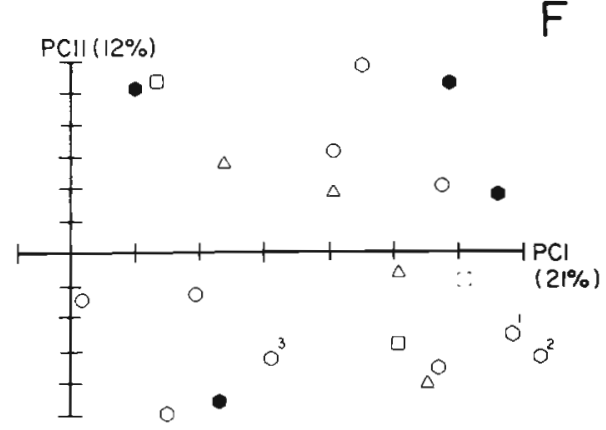

relatively little influence on the observed slope and intercept. However, 2 cases were especially influential. One case is a large coral head $\left(11,340 \mathrm{~cm}^{3}\right)$ from the April flank samples. The predicted number of species from the regression is 14 , but the observed number is only 8 . The other case is also a large coral head $\left(10,875 \mathrm{~cm}^{3}\right)$ from the June flank samples. The predicted number of species from the regression is 14 , but the observed number is 20 . After these 2 cases were deleted, the analysis of covariance was recomputed. Again, there were no significant seasonal effects, but the $F$ ratio for locational differences in slope increased from $5.07(p<.05)$ to $7.72(p<.01)$. This result strengthens the assertion that the species-area regression is significantly steeper for reef flank samples.
Heterogeneous slopes are troublesome in analyses of covariance, because the treatment effect depends on the value of the covariate. The Johnson-Neyman method (Johnson and Neyman, 1936; Huitema, 1980) was used to evaluate the heterogeneous slopes and estimate a non-significance $x$ interval (Table 2). Within this interval, species richness of the flank and flat samples does not differ significantly. Above the interval, reef flank samples (with a steeper slope) have more species; below the interval, reef flat samples (with a flatter slope) are more species rich. The nonsignificance $x$ interval ranges from 2.34 to 6.82 (log scale), which encompasses the range of collected data. Thus, although the flank and flat regression slopes are unequal, average species richness does not differ over 
Table 1. Analyses of covariance results for seasonal and locational effects on abundance and species number. (Influential cases deleted)

\begin{tabular}{|c|c|c|c|c|c|}
\hline Y-variable & Covariate (s) & Factor & $\mathrm{n}$ & $\begin{array}{c}\text { Test for dif- } \\
\text { ferences among } \\
\text { slopes } \\
\text { (F values) }\end{array}$ & $\begin{array}{l}\text { Test for dif- } \\
\text { ferences among } \\
\text { intercepts } \\
\text { (F values) }\end{array}$ \\
\hline $\begin{array}{l}\text { Species } \\
\text { Number }\end{array}$ & Area & $\begin{array}{l}\text { Season } \\
\text { Location }\end{array}$ & 117 & $\begin{array}{l}.43_{(3,109)} \\
7.72_{(1,113)}\end{array}$ & $\begin{array}{l}2.29_{(3,112)} \\
1.91_{(1,114)}\end{array}$ \\
\hline $\begin{array}{l}\text { Species } \\
\text { Number }\end{array}$ & Abundance & $\begin{array}{l}\text { Season } \\
\text { Location }\end{array}$ & 118 & $\begin{array}{l}1.04_{(3,110)} \\
2.24_{(1,114)}\end{array}$ & $\begin{array}{l}1.88_{(3,113)} \\
1.73_{(1,115)}\end{array}$ \\
\hline Abundance & Area & $\begin{array}{l}\text { Season } \\
\text { Location }\end{array}$ & 118 & $\begin{array}{c}.32_{(3.110)} \\
5.03_{(1,114)^{\circ}}\end{array}$ & $\begin{array}{l}\left.4.51_{(3,113)}\right)^{.} \\
9.66_{(1,115)^{*}}\end{array}$ \\
\hline $\begin{array}{l}\text { Species } \\
\text { Number }\end{array}$ & $\begin{array}{l}\text { Area, } \\
\text { Abundance }\end{array}$ & $\begin{array}{l}\text { Season } \\
\text { Location }\end{array}$ & 117 & $\begin{array}{r}.81_{(6,105)} \\
1.72_{(2,111)}\end{array}$ & $\begin{array}{l}1.98_{(3,111)} \\
1.51_{(1,113)}\end{array}$ \\
\hline Significance of $F$ values: & $\therefore \quad \begin{array}{l}\quad p<.05 \\
\therefore \quad p<.01\end{array}$ & & & & \\
\hline
\end{tabular}

Table 2. Contrasts and non-significance intervals for ANCOVA results

\begin{tabular}{ll}
$\begin{array}{l}\text { Adjusted means for abundance/coral head (values in } \\
\text { parentheses estimate untransformed densities) } \\
\text { Season }\end{array}$ & $\overline{\mathrm{Y}} \mathrm{j}$ \\
\hline Jan & $5.64(31.78)$ \\
Apr & $6.63(43.94)$ \\
Jun & $6.49(42.06)$ \\
Aug & $5.71(32.58)$
\end{tabular}

Pairwise comparisons of adjusted mean abundances. A significant value indicates that the 2 samples differ in mean abundance/coral head

Contrast Fisher's protected least significant difference

$\begin{array}{lc}\text { Jan-Apr } & 3.28^{\circ} \\ \text { Jan-Jun } & 2.49^{\circ} \\ \text { Jan-Aug } & .15 \\ \text { Apr-Jun } & .38 \\ \text { Apr-Aug } & 1.90(.05<\mathrm{p}<.10) \\ \text { Jun-Aug } & 3.04^{\circ}\end{array}$

Scheffe's contrasts of adjusted mean abundances

January-April/June-August

(dry season) (wet season)

April-June/January-August

$2.94^{\circ}$

Johnson-Neyman non-significance intervals for heterogeneous slopes of flank-flat comparison. Within this $X$ interval, the flank and flat data do not differ significantly Model Interval

$\begin{array}{lr}\text { Species-area } & 219 \mathrm{~cm}^{3} \text { to } 6,606,934 \mathrm{~cm}^{3} \\ \text { Individuals-area } & 2,570 \mathrm{~cm}^{3} \text { to } 35,480 \mathrm{~cm}^{3} \\ & \\ \therefore< & <05\end{array}$

the range of coral head sizes collected. The flank and flat samples differ statistically, but probably not biologically; the two habitats have similar numbers of species per coral head.

The slope and intercept of the species-individual regression differ neither seasonally nor by location (Fig. 1c). However, there are strong differences in the individuals-area regressions for the different samples. Seasonally, the slopes are equal, but the intercepts differ (Table 1). Density was highest in April ( $\bar{Y}=43.9$ individuals/coral head) and June $(\bar{Y}=42.1)$ and lowest in January $(\bar{Y}=31.8)$ and August $(\bar{Y}=32.6)$. Average density of dry season samples (January and April) did not differ significantly from that of wet season samples (June and August). The contrast of April-June samples, however, was significantly different from that of January-August samples (Table 2).

For the flank-flat comparison, both slopes and intercepts differ significantly (Table 1). The Johnson-Neyman non-significance interval for the individuals-area regression is $2,570 \mathrm{~cm}^{3}$ to $35,480 \mathrm{~cm}^{3}$. Thus, for coral heads smaller than $2570 \mathrm{~cm}^{3}$, reef flat samples had significantly more individuals than reef flank samples. Of the coral heads $67 \%$ were below this size. The upper end of the non-significance interval $\left(35,480 \mathrm{~cm}^{3}\right)$ exceeds the largest coral head collected. Therefore, large reef flank heads do not contain significantly more individuals than large reef flat heads.

It is noteworthy that the individual-area regressions cross in the same fashion as the species-area regressions (Fig. 1d, e). Thus, the heterogeneous slopes of the species-area relation may be caused by differences in abundance.

To test this idea, we repeated the analysis, using both area and the number of individuals as covariates. 
Although the covariate term is significant, slope and intercept differences are not (Table 1). In particular, note that the significant difference in slopes for the species-area relations $\left(F_{1,113}=7.72, p<.01\right)$ is eliminated when abundance of individuals is included in the model $\left(F_{2,111}=1.72, p>.05\right)$. A locational difference in the individuals-area relation produces a corresponding difference in the species-area relation. The species-area regression is steeper for reef flank corals, in part, because the individuals-area regression is also steeper.

Thus, the simplest model accounting for species richness includes only coral head size and abundance of individuals. This multiple regression explains $61 \%$ of the variation in species number. However, this is no greater than a simple regression of species on individuals. Furthermore, the coefficient for area in the multiple regression does not differ significantly from $0(p=.449)$. These results suggest that the most important proximate variable affecting species number is the abundance of individuals. Area may be of importance through its effect on abundance.

\section{Rarefaction}

To evaluate further the species-individual relation, we generated rarefaction curves. Rarefaction estimates the expected number of species in a small sample of individuals drawn randomly from a larger collection with a given species-individual distribution (Hurlbert, 1971; Simberloff, 1978). The data from all coral heads collected in one region and at one time were pooled to generate rarefaction curves. These curves give the expected number of species (and a $95 \%$ confidence interval) in each coral head if all individuals in the sample were distributed randomly among heads. These curves were compared to the actual number of species observed in the heads.

In general, the data are poorly fit by the rarefaction curves (Table 3). For all samples, observations consistently fall below the expected values. Thirty-six of the 119 coral heads had significantly fewer species than expected $(p<.025)$. Only 14 coral heads had more species than expected, and none of these observations was significant. Thus, the distribution of species is 'clumped'. Coral heads have too few species if all individuals from a collection were distributed randomly among heads.

\section{Covariation among groups of species}

To examine covariation among species, a principal components analysis was performed on the $\log _{10}$ abundances of the 23 most common species. The first
Table 3. Observed and expected species number per coral head. Expected values and a $95 \%$ confidence interval are generated by rarefaction for each sample. Numbers of coral heads with significantly fewer species are given in parentheses $(p<.05,2$-tailed); no significant positive deviations were found

\begin{tabular}{|lrc|}
\hline Samples & $\begin{array}{c}\text { Observed species } \\
\text { number < expected }\end{array}$ & $\begin{array}{c}\text { Observed species } \\
\text { number }\end{array}$ \\
\hline January Flat & $25(10)$ & 3 \\
January Flank & $25(6)$ & 3 \\
April Flat & $16(6)$ & 1 \\
April Flank & $12(4)$ & 0 \\
June Flat & $9(3)$ & 3 \\
June Flank & $11(6)$ & 1 \\
August Flat & $3(0)$ & 1 \\
August Flank & $4(1)$ & 14 \\
Total & $105(36)$ & \\
\hline
\end{tabular}

axis accounted for only $21 \%$ of the variation in density. All of the factor loadings were positive, which might be expected because species abundances are usually correlated positively with coral head size. In fact, $\log _{10}$ coral head size accounts for $38 \%$ of the variance $(p<.001)$ in the scores on the first principal component. Subsequent axes account for little residual variance. Four axes are required to explain $50 \%$ of the variance, and nine axes to explain $75 \%$.

The factor loadings for the different species reveal no obvious patterns on the first 2 axes (Fig. 1f). This result is expected, because of the small amount of variance explained by the first 2 principal component axes. Note that Trapezia ferruginea and $T$. corallina, which are significantly correlated in abundance ( $\mathrm{r}=.42, \mathrm{p}=.002)$, have similar loadings on the first 2 axes. Plotting the data by samples did not reveal any obvious seasonal or locational patterns.

A principal components analysis was also performed on presence-absence data for all species. Because many species are rare, this technique gives more equal weight to all species, whereas the PCA on abundances reflects the fluctuations of a few common species. Presence-absence data violate the assumption of multivariate normality, but the violation may not be important unless statistical tests are performed (Green, 1979).

For the presence-absence data, the first axis extracts only $11 \%$ of the variance. Eight axes are required to explain $50 \%$ of the variance, and 15 axes to explain $75 \%$. Unlike the abundance analysis, the first principal component for the presence-absence data has both positive and negative loadings. Both the first and the second principal components are weakly correlated with coral head size $(\mathrm{PCI} r=.25, \mathrm{p}<.05$; PCII $\mathrm{r}=.35$, 
$\mathrm{p}<.01$ ). Again, no obvious patterns emerge from the factor loadings on the first 2 axes.

\section{Covariation among species pairs}

To study patterns of interspecific association, correlation coefficients of abundance were calculated for selected species pairs. This statistic reveals whether the abundances of pairs of species covary positively, negatively, or independently of each other. Hurlbert (1969) warns that correlation coefficients may be misleading because they reflect both covariation among species densities (correlation) and the degree of association between species (as measured by presence-absence data). In addition, abundance data usually violate the assumption of normality required for correlation.

However, the correlation coefficient is still a useful measure of covariation, because confounding variables can be factored out. For example, most species abundances increase with coral head size, so positive correlations between densities may be spurious. A partial correlation coefficient, factoring out the effect of coral head size, would more accurately reflect the degree of covariation between the species. In addition, the effect of other species can be partialled out of any pairwise comparison.

Correlations among the seven most common species were examined, using log densities to meet better the assumption of normality. For each pairwise comparison, the effects of coral head size and the abundance of the other 5 species were statistically partialled out. For all the data, only 2 comparisons were significant ( $p<.05,2$-tailed) and both were positive correlations (Table 4). The congeneric xanthids Trapezia ferruginea and $T$. corallina were positively correlated. $T$. corallina was also positively correlated with the snapping shrimp Alpheus lottini. None of the other 19 pairs was significant in either direction.

However, the results are different if only those samples with both species present are used. In this case, 2 significant negative correlations also appear (Table 4). The congeners Trapezia corallina and $T$. formosa are negatively correlated. $T$. formosa is also negatively correlated with the palaeomonid shrimp Fennera chacei Holthuis. T. corallina is positively correlated with both $T$. ferruginea and the shrimp Harpiliopsis depressus (Stimpson). Although some of the significance levels change, the patterns are similar if the data are divided by season or location.

Statistical tests are problematic for these sorts of data. With 21 comparisons, at least 1 or 2 significant results are expected by chance alone. If the significance level is appropriately reduced to maintain an overall error rate of .05 , then only the positive correlation between Trapezia ferruginea and $T$. corallina is significant.

Overall, species abundances do not appear strongly correlated. In particular, note that negative correlations only emerge on coral heads where both species are present. Total abundances covary positively in 2 cases, independently in all the rest. Positive correlations are just as frequent as negative ones, and both congeneric and non-congeneric pairs may be significantly correlated. Patterns of covariation do not appear

Table 4. Partial correlation coefficients of abundances of pairs of common species. Coral head size and the abundance of other species factored out; all samples used. (Only samples with both species present used for values in parentheses)

\begin{tabular}{|c|c|c|c|c|c|c|}
\hline & $\begin{array}{l}\text { Trapezia } \\
\text { corallina }\end{array}$ & $\begin{array}{l}\text { Trapezia } \\
\text { formosa }\end{array}$ & $\begin{array}{l}\text { Alpheus } \\
\text { lottini }\end{array}$ & $\begin{array}{c}\text { Harpiliopsis } \\
\text { depressus }\end{array}$ & $\begin{array}{c}\text { Fennera } \\
\text { chacei }\end{array}$ & $\begin{array}{l}\text { Teleophrys } \\
\text { cristulipes }\end{array}$ \\
\hline $\begin{array}{l}\text { Trapezia } \\
\text { ferruginea }\end{array}$ & $\begin{array}{l}.42^{\cdots} \\
(.40)^{\cdots}\end{array}$ & $\begin{array}{c}14 \\
(.22)\end{array}$ & $\begin{array}{l}.05 \\
(.12)\end{array}$ & $\begin{array}{c}.02 \\
(-.11)\end{array}$ & $\begin{array}{l}.18 \\
(.05)\end{array}$ & $\begin{array}{l}.21 \\
(.15)\end{array}$ \\
\hline $\begin{array}{l}\text { Trapezia } \\
\text { corallina }\end{array}$ & & $\begin{array}{l}-.04 \\
(-.42)\end{array}$ & $\begin{array}{l}.31^{\circ} \\
(.23)\end{array}$ & $\frac{.24}{(.31)^{\cdots}}$ & $\begin{array}{l}-.18 \\
(-.06)\end{array}$ & $\begin{array}{l}.16 \\
(.06)\end{array}$ \\
\hline $\begin{array}{l}\text { Trapezia } \\
\text { formosa }\end{array}$ & & & $\begin{array}{c}21 \\
(.10)\end{array}$ & $\begin{array}{c}14 \\
(.31)\end{array}$ & $\begin{array}{c}11 \\
(-.54)\end{array}$ & $\begin{array}{l}-.05 \\
(.24)\end{array}$ \\
\hline $\begin{array}{l}\text { Alpheus } \\
\text { lottini }\end{array}$ & & & & $\begin{array}{l}-.03 \\
(-.05)\end{array}$ & $\begin{array}{r}.05 \\
(-.08)\end{array}$ & $\begin{array}{c}.13 \\
(-.14)\end{array}$ \\
\hline $\begin{array}{l}\text { Harpiliopsis } \\
\text { depressus }\end{array}$ & & & & & $\begin{array}{l}.25 \\
(.24)\end{array}$ & $\begin{array}{l}-.05 \\
(-.09)\end{array}$ \\
\hline $\begin{array}{l}\text { Fennera } \\
\text { chacei }\end{array}$ & & & & & & $\begin{array}{l}.05 \\
(.01)\end{array}$ \\
\hline $\begin{array}{l}\cdot<.05 \\
\cdot<.01\end{array}$ & & & & & & \\
\hline
\end{tabular}


to change much in different seasons or different locations.

Hurlbert's (1969) $\mathrm{C}_{8}$ index was calculated to measure species associations. This statistic measures association based upon presence-absence data, whereas the correlation coefficient measures the degree of covariation between the densities of species. As measured by $\mathrm{C}_{8}$, most associations of species pairs are very close to 0 . Trapezia ferruginea and $T$. corallina are not associated with any other species $\left(\mathrm{C}_{8}=0\right)$ because they are present on every coral head. T. formosa and Fennera chacei show weak positive association $\left(C_{B}=0.34\right.$, $\mathrm{p}>.05)$ but covary negatively in their abundances $(r=-0.54, p=.009)$. Association indices were also calculated for some congeneric pairs of synalpheid shrimps and porcellanid crabs (Table 5). The con-

Table 5. Association indices $\left(C_{8}\right)$ for some congeneric pairs of species

$\begin{array}{lr}\text { Harpiliopsis spinigerus } \times \text { Harpiliopsis depressus } & -.06 \\ \text { Petrolisthes edwardsi } \times \text { Petrolisthes haigae } & .06 \\ \text { Petrolisthes edwardsi } \times \text { Petrolisthes glasselli } & .00 \\ \text { Petrolisthes haigae } \times \text { Petrolisthes glasselli } & .00 \\ \text { Synalpheus charon } \times \text { Synalpheus mexicanus } & .26 \\ \text { Synalpheus charon } \times \text { Synalpheus diguieti } & .09 \\ \text { Synalpheus mexicanus } \times \text { Synalpheus diguieti } & .00 \\ & \\ \mathrm{p}<.05 & \end{array}$

geners Synalpheus charon (Heller) and $S$. cf. mexicanus are positively associated $\left(\mathrm{C}_{8}=0.26, \mathrm{p}<.05\right)$, but all other comparisons are close to 0 .

\section{DISCUSSION}

For decapods inhabiting Pocillopora, the speciesarea relation is a function of both reef location and density of individuals. Small coral heads support more individuals on the reef flat than on the reef flank, and this pattern influences the shape of the species-area regression. One explanation for this finding is provided by Preston (1962). Reef flank corals are patchily distributed and might behave like true 'isolates' with low migration of decapods between coral heads. Coral cover is more continuous on the reef flat, where increased decapod migration could produce a shallower species-area regression. However, turnover rates have never been determined for decapods of Pocillopora. It would be premature to suggest that equilibrium is maintained as in the MacArthur-Wilson (1967) model.

Furthermore, the reef flat and reef flank at Uva are subject to very different abiotic regimes. Extensive areas of reef flat corals may be killed by lengthy lowtide exposures (Glynn, 1976). This mortality may affect the community structure of reef flat decapods. The fauna associated with dead Pocillopora differs in both associated species richness and identity from that of live coral (Abele, 1976b; Coles, 1980).

Coral eating fishes are very common on the reef flank at Uva (Glynn et al., 1972) and may affect the densities of decapod associates. In laboratory experiments, Castro (1978) showed that Trapezia migration was considerably reduced in the presence of carnivorous fish. Thus, predation could account for lower abundances on small reef flank corals. Decapod associates of Stylophora in the Red Sea are also less common on reef flank corals (Edwards and Emberton, 1980).

At Uva, seasonal differences in density are evident, but did not translate into differences in species richness; the species-area relation remains constant throughout the year. Moreover, these density changes are not coincident with the wet-dry season cycle in the Eastern Pacific. This may not be so surprising, because physical conditions in the Gulf of Chiriqui are relatively constant (Abele, 1976a); seasonal upwelling does not occur, and annual temperature changes are slight, though significant (Dana, 1975).

It is important to note the effects of including abundance in the species-area model. Because abundance directly influences the shape of the species-area regression, analyses based entirely on presence-absence data may be incomplete. Geographic comparisons of species-area regressions may be confounded by density effects.

On the spatial scale of a single coral head, species interactions may also affect patterns of co-occurrence and abundance. Several 'neutral models' (sensu Caswell, 1976) were examined with the hope of detecting such interactions. Rarefaction curves suggest that most coral heads have fewer species than expected if individuals from a sample were distributed randomly among heads. Interspecific competition could produce this result, although alternative mechanisms are equally plausible (Dillon, 1981). For the Pocillopora community, a partial explanation is that coral heads are colonized by male-female pairs, rather than single individuals of a species. All species of Trapezia, the snapping shrimp Alpheus lottini, and some species of the genus Synalpheus associate as male-female pairs on coral heads (Abele, 1979).

A principal components analysis was used to detect any major patterns of covariation among species' densities. The low percent of variation explained by any single axis suggests that most species covary independently in abundance. Our findings are similar to those of Shulenberger (1980) for hyperiid amphipod assemblages and Wiens and Rotenberry (1981) for 
shrubsteppe bird communities. Neither study detected any major patterns of covariation in species' abundances. In this case, the first component of variation seems to be a function of coral head size.

Association and correlation indices also suggest that most species covary independently of each other. Few significant correlations emerged from 21 pairwise comparisons. For the 3 Trapezia species, 1 pair was positively correlated in abundance, and 1 pair negatively correlated. Association was near 0 because $T$. ferruginea and $T$. corallina are found on every coral head.

These findings contrast sharply with Preston's (1973) analysis of the 5 species of Trapezia in Hawaii. Preston (1973) found 7 out of 10 pairwise comparisons had negative values for $\mathrm{C}_{8}$. This result was obtained because Trapezia species in Hawaii are preferentially associated with different sized coral heads (Preston, 1973). Thus, $\mathrm{C}_{8}$ values are confounded by size effects and may not be indicative of species interactions. In contrast, the Trapezia species in the Eastern Pacific Ocean can be found on all sizes of coral heads and have association indices $\left(\mathrm{C}_{8}\right)$ of 0 . These differences between Hawaiian and Eastern Pacific Trapezia are striking. The Pocillopora habitat is similar, and 2 of the species ( $T$. ferruginea and $T$. digitalis) are present in both areas. However, Pocillopora heads are widely scattered in Hawaii (Preston, 1973) and form dense reefs in the Eastern Pacific (Glynn, 1976).

Both inter- and intraspecific interactions have been reported for Pocillopora decapods (Preston, 1971; Lassig, 1977; Castro, 1978). Yet, most species show considerable independence in their patterns of abundance and co-occurrence. Either species interactions are not strong enough to influence these patterns, or the interactions are complex and are not manifest in these statistics. An experimental study is needed to distinguish between these alternatives. An obvious approach would be to manipulate species pairs with negative association or correlation indices. These manipulations would be most likely to reveal any interspecific effects.

Acknowledgements. We thank Peter Glynn for access to the Uva Island collections. Don Strong, Joe Travis, Craig Young and 3 anonymous reviewers provided useful comments on the manuscript.

\section{LITERATURE CITED}

Abele, L. G. (1976a). Comparative species richness in fluctuating and constant environments: coral-associated decapod crustaceans. Science, N. Y 192: 461-463

Abele, L. G. (1976b). Comparative species composition and relative abundance of decapod crustaceans in marine habitats of Panama. Mar. Biol. 38: 263-278
Abele, L. (1979). The community structure of coral-associated decapod crustaceans in variable environments. In: Livingston, R. J. (ed.) Ecological processes in coastal and marine systems. Plenum Press, New York, p. 265-287

Abele, L. G. (in press). Biogeography, colonization and experimental structure of coral-associated crustaceans. In: Strong, D. R., Simberloff, D. S., Abele, L. G., Thistle, A. B. (ed.) Ecological communities: conceptual issues and the evidence. Princeton University Press, Princeton, N. J.

Abele, L. G., Patton, W. K. (1976). The size of coral heads and the community biology of associated decapod crustaceans. J. Biogeogr. 3: 35-47

Austin, A. D., Austin, S. A., Sale, P. F. (1980). Community structure of the fauna associated with the coral Pocillopora damicornis (L.) on the Great Barrier Reef. Aust. J. mar. Freshwat. Res. 31: 163-174

Barry, C. K. (1965). Ecological study of the decapod crustaceans commensal with the branching coral Pocillopora meandrina var. nobilis Verrill. M.S. thesis, University of Hawaii, Honolulu, Hawaii

Castro, P. (1976). Brachyuran crabs symbiotic with scleractinian corals; a review of their biology. Micronesia 12 99-110

Castro, P. (1978). Movements between corals colonies in Trapezia ferruginia (Crustacea: Brachyura), an obligate symbiont of scleractinian corals. Mar. Biol. 46: 237-245

Castro, P. (in press). Notes on symbiotic decapod crustaceans from Gorgona Islands, Columbia, with a preliminary revision of the eastern Pacific species of Trapezia (Brachyura, Xanthidae), symbionts of the scleractionian corals. An. Inst. Inv. Mar. Punta Betin 12

Caswell, H. L. (1976). Community structure: a neutral model analysis. Ecol. Monogr. 46: 327-354

Coles, S. L. (1980). Species diversity of decapods associated with living and dead reef coral Pocillopora meandrina. Mar. Ecol. Prog. Ser. 2: 281-291

Dana, T. F. (1975). Development of contemporary Eastern Pacific coral reefs. Mar. Biol. 33: 355-374

Dillon, R. T. (1981). Patterns in the morphology and distribution of gastropods in Oneida Lake, New York, detected using computer-generated null hypotheses. Am. Nat. 118: 83-101

Edwards, A., Emberton, H. (1980). Crustacea associated with the scleractinian coral, Stylophora pistillata (Esper), in the Sudanese Red Sea. J. exp. mar. Biol. Ecol. 42: 225-240

Garth, J. S. (1964). The Crustacea Decapods (Brachyura and Anomura) of Eniwetok Atoll, Marshall Islands, with special reference to the obligate commensals of branching corals. Micronesia 1: 137-144

Garth, J. S. (1974). Decapod crustaceans inhabiting reefbuilding corals of Ceylon and the Maldive Islands. J. mar. biol. Ass. India 15: 195-212

Glynn, P. W. (1973). Acanthaster: effect on coral reef growth in Panama. Science, N. Y. 180: 504-506

Glynn, P. W. (1976). Some physical and biological determinants of coral community structure in the eastern Pacific. Ecol. Monogr. 46: 431-456

Glynn, P. W. (1980). Defense by symbiotic crustacea of host corals elicited by chemical cues from predators. Oecologia 47: $287-290$

Glynn, P. W., Stewart, R. H., McCosker, J. E. (1972). Pacific coral reefs of Panama: structure, distribution, and predators. Geol. Rdsch. 61: 483-519

Green, R. H. (1979). Sampling design and statistical methods for environmental biologists. John Wiley and Sons, New York 
Haila, Y., Järvinen, O. (1981). The underexploited potential of quantitative bird censuses in insular ecology. Studies in Avian Biology 6: 559-565

Hairston, N. G. (1982). An experimental test of a guild: salamander competition. Ecology 62: 65-72

Huitema, B. E. (1980). The analysis of convariance and alternatives. John Wiley and Sons, Inc., New York

Hurlbert, S. H. (1969). A coefficient of interspecific association. Ecology 50: 1-9

Hurlbert, S. H. (1971). The nonconcept of species diversity: a critique and alternative parameters. Ecology 52: 577-586

Johnson, P. O., Neyman, J. (1936). Tests of certain limear hypotheses and their application to some educational problems. Statist. Res. Mem. Univ. Coll. Lond. 1: 57-93

Knudsen, J. W. (1967). Trapezia and Tetralia (Decapoda, Brachyura, Xanthidae) as obligate ectoparasites of pocilloporid and acroporid corals. Pacif. Sci. 21: 51-57

Lassig, B. R. (1977). Communication and coexistence in a coral community. Mar. Biol. 42: 85-92

Lawton, J. H., Strong, D. R., Jr. (1981). Community patterns and competition in folivorous insects. Am. Nat. 118: 317-338

MacArthur, R. H. (1972). Geographical ecology: patterns in the distribution of species. Harper and Row, New York

MacArthur, R. H., Wilson, E. O. (1967). The theory of island biogeography. Princton University Press, Princeton, N. J.

Patton, W. K. (1966). Decapod crustacea commensal with Queensland branching corals. Crustaceana 10: 271-295

Patton, W. K. (1974). Community structure among the animals inhabiting the coral Pocillopora damicornis at Heron Island, Australia. In: Vernberg, W. B. (ed.) Symbiosis in the sea. University of South Carolina Press, Columbia, p. $219-243$
Pielou, E. C. (1977). Mathematical ecology. John Wiley and Sons, Inc., New York

Preston, F. W. (1962). The canonical distribution of commonness and rarity. Ecology $43: 185-215 ; 410-432$

Preston, E. M. (1971). Niche overlap and competition among five sympatric congeneric species of xanthid crabs. Ph. D thesis, University of Hawaii, Honolulu, Hawaii

Preston, E. M. (1973). A computer simulation of competition among five sympatric congeneric species of xanthid crabs. Ecology 54: 469-483

Reed, J. K., Gore, R. H., Scotto, L. E., Wilson, K. A. (1982) Community composition, structure, areal and trophic relationships of decapods associated with shallow- and deepwater Oculina varicosa coral reefs: studies on the decapod crustacea from the Indian River region of Florida, XXIV. Bull. mar. Sci. 32: 761-786

Shulenberger, E. (1980). Factor analyses of a hyperiid amphipod assemblage from the North Pacific Central Gyre. Mar. Ecol. Prog. Ser. 2: 109-120

Simberloff, D. S. (1978). Use of rarefaction and related methods in ecology. In: John Cairns, Jr., Dickson, K. L., Livingston, R. J. (ed.) Biological data in water pollution assessment: quantitative and statistical analyses, ASTM STP 652 (Am. Soc. for Testing and Materials), p. 150-165

Weisberg, S. (1980). Applied linear regression. New York Wiley

Whittam, T. S., Siegel-Causey, D. (1981). Species interactions and community structure in Alaskan seabird colonies. Ecology 62: 1515-1524

Wiens, J. A., Rotenberry, J. T. (1981). Habitat associations and community structure of birds in shrubsteppe environments. Ecol. Monogr. 51: 21-41 